\title{
ISTRAŽIVANJA RAZNOLIKOSTI MORFOLOŠKIH SVOJSTAVA HRASTA LUŽNJAKA (Quercus robur L.) U POKUSU PROVENIJENCIJA ŽEPČE, BOSNA I HERCEGOVINA*
}

\section{RESEARCH OF DIVERSITY OF MORPHOLOGICAL TRAITS OF PEDUNCULATE OAK (Quercus robur L.) IN PROVENANCE TEST ŽEPČE, BOSNIA AND HERZEGOVINA}

Mirzeta MEMIŠEVIĆ HODŽIĆ ${ }^{*}$, Dalibor BALLIAN ${ }^{2,3}$

\begin{abstract}
Sažetak
Prirodne populacije hrasta lužnjaka (Quercus robur L.) u Bosni i Hercegovini su male i rascjepkane. Razlikuju se od onih koje se nalaze u svom optimumu u srednjoj Europi, svojom specifičnom genetskom strukturom, te imaju važnu ulogu u očuvanju raznolikosti hrasta lužnjaka u Europi.

Cilj ovog istraživanja je odrediti varijabilnost populacija hrasta lužnjaka u Bosni i Hercegovini.

U testu provenijencija u rasadniku Žepče, u proljeće 2012., 2013. i 2014. godine provedeno je mjerenje visina biljaka i promjera vrata korijena. Izmjerene su sve preživjele bilike u svih 28 provenijencija.

Najmanju prosječnu visinu biljaka 2012. godine imala je provenijencija Miljevina, $38,8 \mathrm{~cm}$, a najveću Jelah 74,3 $\mathrm{cm}$. U 2013. godini, najmanju prosječnu visinu imala je provenijencija Stojčevac, $61,3 \mathrm{~cm}$, dok provenijencija Jelah ostaje provenijencija sa najvećom prosječnom visinom, 108,4 cm. Provenijencija Miljevina i dalje ima prosječnu visinu vrlo nisku, $63,0 \mathrm{~cm}$. U 2014. godini najmanju prosječnu visinu zadržava provenijencija Stojčevac, $90,8 \mathrm{~cm}$ a najveću provenijencija Jelah, $152,1 \mathrm{~cm}$.

Najmanji srednji promjer vrata korijena za 2012. godinu imala je provenijencija Vinac, 11,3 mm, a najveći provenijencija Jelah, 16,2 mm. Najmanji srednji promjer vrata korijena za 2013. godinu imala je provenijencija Stojčevac, $17,9 \mathrm{~mm}$, a najveći provenijencija Jelah, $23,8 \mathrm{~mm}$. Provenijencija Vinac se pomakla za sedamnaest mjesta s prosječnim promjerom vrata korijena $19,9 \mathrm{~mm}$. Najmanji srednji promjer vrata korijena za 2014. godinu zadržala je provenijencija Stojčevac, s vrijednošću $23,7 \mathrm{~mm}$, dok najveći promjer korijenovog vrata ima provenijencija Jelah, $34,7 \mathrm{~mm}$. Analiza varijance pokazala je statistički značajne razlike između populacija po svim ispitivanim svojstvima, što je potvrdio i Duncan test.
\end{abstract}

KLJUČNE RIJEČl: hrast lužnjak, test provenijencija, morfološka varijabilnost

\footnotetext{
1 Dr. sc. Mirzeta Memišević Hodžić, JP “Bosanskohercegovačke šume”, Maršala Tita 7, 71000 Sarajevo, Bosna i Hercegovina, mirzeta.memisevic.hodzic@gmail.com

2 Prof. dr. Dalibor Ballian, Šumarski fakultet, Univerzitet u Sarajevu, Zagrebačka 20, 71000 Sarajevo, Bosna i Hercegovina, balliandalibor9@gmail.com

${ }^{3}$ Gozdarski inštitut Slovenije, Večna pot 2, 1000 Ljubljana, Slovenia

* Ovo istraživanje je dio Doktorske disertacije Mirzete Memišević Hodžić, obranjene na Šumarskom fakultetu Univerziteta u Sarajevu
} 


\section{UVOD}

\section{INTRODUCTION}

Hrast lužnjak (Quercus robur L.) je nekad predstavljao važnu ekonomsku vrstu bosanskohercegovačkih šuma (Begović 1960, 1978), ali su šume lužnjaka neplanskom eksploatacijom uništene. Prema Klepcu (1988) preostale tadašnje površine šuma hrasta lužnjaka iznosile su oko 30.000 ha. Tako se prema istom autoru, najkvalitetnije šume hrasta lužnjaka u Bosni i Hercegovini nalaze na području općina Bosanski Šamac, Bosanska Gradiška, Brčko i Bijeljina, a najstarije u općini Bosanska Gradiška. Veći dio čine privatne, manje, uglavnom izdanačke šume.

Općenito najveće rasprostranjenje hrasta lužnjaka u Bosni i Hercegovini je u Posavini, gdje i pored rascjepkanosti možemo reći da ima kompaktno područje rasprostiranja od donjeg toka Drine do donjeg toka Une. Također hrast lužnjak se duž većih bosanskih rijeka uvlači duboko u unutrašnjost. Nalazimo ga i u submediteranskom području, u Livanjskom i Posuškom polju na nadmorskoj visini od 700 m (Begići i Ballian 2009). Lužnjak je prisutan i na planinskoj visoravni izmedu Mrkonjić grada i Ključa, na nadmorskoj visini od $750 \mathrm{~m}$, pojedinačno uz potok. Na Petrovačkom polju u Bosanskoj krajini pridolazi pojedinačno ili u manjim skupinama, pretežno u vrtačama. Na Glasinačkoj visoravni, na planini Romaniji kod Sokoca raste na oko 850 metara nadmorske visine, gradi visinsku varijantu lužnjakove šume (Quercetum roboris montanum) (Jovančević 1966, 1968), kao i u području susjedne Knežine.

Prema Pintariću (2002), Matiću (2009) i Bobincu (2011) hrast lužnjak je klimatski i edafski vrlo plastična vrsta, što je omogućilo pojavu velikog broja varijeteta. Bolje podnosi kontinentalnu i submediteransku klimu nego hrast kitnjak. U našoj se zemlji održava, uglavnom, na aluvijalnim i deluvijalnim, razvijenim i nerazvijenim mineralno-močvarnim tlima, koja su od jeseni do proljeća prosječno vlažna do mokra, ljeti često suha, teška i zbijena, najviše na raznim varijantama i prelazima podzola, pseudogleja, mineralnomočvarnim tlima i sl.

Istraživanja hrasta lužnjaka na području Bosne i Hercegovine do sada su se provodila relativno rijetko. Bašić i dr. (2007) i Memišević i dr. (2010) u istraživanju lisnog materijala hrasta lužnjaka, utvrdili su značajne unutarpopulacijske i međupopulacijske razlike, s tim da su na unutarpopulacijskoj razini veće nego na međupopulacijskoj. Ballian i dr. (2011) publicirali su prve rezultate o rastu i preživljavanju hrasta lužnjaka u testu provenijencija Žepče. Kako su to bili samo preliminarni rezultati, nisu od većeg značenja.

Za razliku od Bosne i Hercegovine u susjednoj Hrvatskoj je proveden velik broj istraživanja morfoloških svojstava hrasta lužnjaka (Franjić 1993, 1993a, 1994, 1996; Bogdan i dr. 2009). Kada su u pitanju morfološka istraživanja u testovima provenijencija, prva značajnija istraživanja provodi Gračan
$(1995,1996)$ koji analizira hrast lužnjak iz više provenijencija na dva lokaliteta. Na istim lokalitetima daljnja istraživanja provode i drugi autori (Perić 2001; Perić i dr. 2000, 2003, 2006, 2007, 2008). Slijedi Roth (2003) koji je analizirao lužnjak u rasadničkom pokusu. Zadnja istraživanja provodi Popović i dr. (2014) na novom pokusu provenijencija hrasta lužnjaka u Hrvatskoj, podrijetlom iz sjemenskih sastojina.

Kada je u pitanju genetska varijabilnost, u Bosni i Hercegovini Ballian i dr. (2010) ispitivali su varijabilnost nekih od populacija i skupina stabala lužnjaka na molekularno genetičkoj razini, korištenjem visoko polimorfnih nuklearnih mikrosatelitskih biljega. Zabilježene su značajne razlike u frekvencijama između populacija. Nešto ranije Slade i dr. (2008) su analizirali haplotipove 110 populacija hrastova iz područja centralnog Balkana, korištenjem četiri RFLP biljega. Najveća varijabilnost haplotipova pronađena je u dolini Neretve, a analizirano je i pet populacija hrasta lužnjaka iz Bosne i Hercegovine.

Populacije hrasta lužnjaka u Bosni i Hercegovini predstavljaju specifične zajednice u nestajanju, a koje se razlikuju od onih iz svog optimuma u srednjoj Europi. Zbog velike genetske raznolikosti koju pokazuju prirodne populacije hrasata lužnjaka u Bosni i Hercegovini (Ballian i dr. 2010) jako su značajne za očuvanje genetske raznolikosti hrasta lužnjaka u Europi. Kako učinkovitost mjera očuvanja i reintrodukcija ovise o stupnju poznavanja varijabilnosti, jedan od načina kako doći do kvalitetnih rezultata je i postavljanje terenskih pokusa provenijencija. Sam pokus provenijencija hrasta lužnjaka u rasadniku Žepče predstavlja očuvanje hrasta lužnjaka metodom ex situ, a dobiveni rezultati iz navedenog pokusa će dati obilje podataka potrebnih za očuvanje metodama in situ.

Cilj istraživanja je utvrđivanje varijabilnosti unutar i između provenijencija hrasta lužnjaka mjerenjem morfoloških svojstava, visina i promjera na vratu korijena, tijekom tri godine.

\section{MATERIJAL I METODA RADA MATERIAL AND METHODS}

Sjemenski materijal hrasta lužnjaka za postavljanje pokusa provenijencija je sakupljen tijekom 2007. godine na 28 lokaliteta (populacija) u Bosni i Hercegovini. Odmah je tijekom jeseni 2007. godine u rasadniku Žepče - Lugovi provedena sjetva sjemena u Dunemann-ove lijehe, prema unaprijed napravljenom rasporedu. Kod starosti biljaka $1+0$ je postavljen trajni pokus provenijencija. Sadnja biljaka u terenski pokus obavljena je u proljeće 2009. godine na klasičan način, sadnjom u rupe dubine $30 \mathrm{~cm}$, na razmaku sadnje od $2 \mathrm{~m} \times 2 \mathrm{~m}$. Svaka provenijencija je prema shemi posađena u tri bloka (3 ponavljanja) po slučajnom rasporedu, sa 36 biljaka po provenijenciji u svakom bloku. Oko svakog bloka podignut je zaštitni pojas od dva reda sadnica u cilju umanjenja rubnih efekata na pokusnoj površini (Shema 1.). 
Tablica 1: Pregled istraživanih provenijencija

Table 1: List of investigated provenances

\begin{tabular}{|c|c|c|c|c|c|}
\hline $\begin{array}{l}\text { R. br. } \\
\text { No. }\end{array}$ & $\begin{array}{c}\text { Provenijencije } \\
\text { Provenance }\end{array}$ & $\begin{array}{l}\text { Lokalitet } \\
\text { Locality }\end{array}$ & $\begin{array}{l}\text { Sjev. g. širina } \\
\text { Latitude }\end{array}$ & $\begin{array}{l}\text { Ist. g. dužina } \\
\text { Longitude }\end{array}$ & $\begin{array}{c}\text { NV } \\
\text { Altitude }\end{array}$ \\
\hline 1 & Bijeljina & Patkovača & $44^{\circ} 43^{\prime} 50^{\prime \prime}$ & $19^{\circ} 13^{\prime} 30^{\prime \prime}$ & 93 \\
\hline 2 & Bosanska Dubica & Knežica & $45^{\circ} 06^{\prime} 24^{\prime \prime}$ & $16^{\circ} 40^{\prime} 32^{\prime \prime}$ & 145 \\
\hline 3 & Bosanska Gradiška & Lipnica & $45^{\circ} 06^{\prime} 64^{\prime \prime}$ & $17^{\circ} 18^{\prime} 63^{\prime \prime}$ & 91 \\
\hline 4 & Bosanski Brod & Zborišta & $45^{\circ} 05^{\prime} 27^{\prime \prime}$ & $18^{\circ} 00^{\prime} 38^{\prime \prime}$ & 84 \\
\hline 5 & Bosansko Grahovo & Crni lug & $44^{\circ} 01^{\prime} 05^{\prime \prime}$ & $16^{\circ} 38^{\prime} 24^{\prime \prime}$ & 703 \\
\hline 6 & Bugojno & Kopčić & $44^{\circ} 06^{\prime} 00^{\prime \prime}$ & $17^{\circ} 26^{\prime} 31^{\prime \prime}$ & 537 \\
\hline 7 & Drvar & Unac & $44^{\circ} 23^{\prime} 39^{\prime \prime}$ & $16^{\circ} 21^{\prime} 54^{\prime \prime}$ & 462 \\
\hline 8 & Srebrenik & Hrgovi & $44^{\circ} 49^{\prime} 06^{\prime \prime}$ & $18^{\circ} 34^{\prime} 11^{\prime \prime}$ & 133 \\
\hline 9 & Jelah & - & $44^{\circ} 39^{\prime} 09^{\prime \prime}$ & $17^{\circ} 56^{\prime} 46^{\prime \prime}$ & 181 \\
\hline 10 & Kaćuni & Nezirovići & $44^{\circ} 03^{\prime} 59^{\prime \prime}$ & $17^{\circ} 56^{\prime} 13^{\prime \prime}$ & 443 \\
\hline 11 & Kiseljak & Dalmacija & $43^{\circ} 56^{\prime} 30^{\prime \prime}$ & $18^{\circ} 04^{\prime} 56^{\prime \prime}$ & 477 \\
\hline 12 & Ključ & Velečevo & $44^{\circ} 30^{\prime} 56^{\prime \prime}$ & $16^{\circ} 48^{\prime} 42^{\prime \prime}$ & 260 \\
\hline 13 & Knežina & - & $44^{\circ} 01^{\prime} 40^{\prime \prime}$ & $18^{\circ} 44^{\prime} 53^{\prime \prime}$ & 759 \\
\hline 14 & Kotor Varoš & - & $44^{\circ} 39^{\prime} 07^{\prime \prime}$ & $17^{\circ} 21^{\prime} 35^{\prime \prime}$ & 252 \\
\hline 15 & Lukavica & - & $43^{\circ} 49^{\prime} 26^{\prime \prime}$ & $18^{\circ} 21^{\prime} 58^{\prime \prime}$ & 552 \\
\hline 16 & Miljevina Foča & Miljevina & $43^{\circ} 31^{\prime} 06^{\prime \prime}$ & $18^{\circ} 38^{\prime} 56^{\prime \prime}$ & 627 \\
\hline 17 & Mrkonjić Grad & Čađavica & $44^{\circ} 27^{\prime} 04^{\prime \prime}$ & $16^{\circ} 58^{\prime} 42^{\prime \prime}$ & 753 \\
\hline 18 & Cazin & Mutnica & $44^{\circ} 58^{\prime} 55^{\prime \prime}$ & $15^{\circ} 50^{\prime} 54^{\prime \prime}$ & 270 \\
\hline 19 & Nević polje & - & $44^{\circ} 11^{\prime} 46^{\prime \prime}$ & $17^{\circ} 42^{\prime} 11^{\prime \prime}$ & 476 \\
\hline 20 & Olovo & Olovske luke & $44^{\circ} 07^{\prime} 44^{\prime \prime}$ & $18^{\circ} 36^{\prime} 11^{\prime \prime}$ & 542 \\
\hline 21 & Sokolac & Lug & $43^{\circ} 55^{\prime} 17^{\prime \prime}$ & $18^{\circ} 48^{\prime} 53^{\prime \prime}$ & 866 \\
\hline 22 & Ilidža & Stojčevac & $43^{\circ} 48^{\prime} 40^{\prime \prime}$ & $18^{\circ} 17^{\prime} 25^{\prime \prime}$ & 506 \\
\hline 23 & Vinac & Bila Voda & $44^{\circ} 15^{\prime} 48^{\prime \prime}$ & $17^{\circ} 17^{\prime} 08^{\prime \prime}$ & 408 \\
\hline 24 & Visoko & Muhašinovići & $44^{\circ} 00^{\prime} 38^{\prime \prime}$ & $18^{\circ} 08^{\prime} 45^{\prime \prime}$ & 413 \\
\hline 25 & Zavidovići & Grad & $44^{\circ} 26^{\prime} 07^{\prime \prime}$ & $18^{\circ} 07^{\prime} 49^{\prime \prime}$ & 210 \\
\hline 26 & Zvornik & Aluminij & $44^{\circ} 25^{\prime} 01^{\prime \prime}$ & $19^{\circ} 07^{\prime} 22^{\prime \prime}$ & 141 \\
\hline 27 & Žepče & Žepački lug & $44^{\circ} 25^{\prime} 35^{\prime \prime}$ & $18^{\circ} 03^{\prime} 10^{\prime \prime}$ & 224 \\
\hline 28 & Živinice & D. Dubrave & $44^{\circ} 27^{\prime} 58^{\prime \prime}$ & $18^{\circ} 41^{\prime} 09^{\prime \prime}$ & 216 \\
\hline
\end{tabular}

Mjerene su visine i promjeri na vratu korijena u proljeće 2012., 2013. i 2014. godine. Podaci su obrađeni statističkim paketom SPSS 20.0 i dobijeni su sljedeći parametri:

- Deskriptivni statistički pokazatelji (srednja vrijednost, standardna devijacija, minimalna i maksimalna vrijednost i koeficijent varijabilnosti),

- Analiza varijance za utvrđivanje unutarpopulacijske i međupopulacijske varijabilnosti,

- Duncanov test za utvrđivanje grupiranja provenijencija po istraživanim svojstvima.

\section{REZULTATI RESULTS}

\subsection{Rezultati visina - Results of plant height}

Kao što se vidi u tablici 2 i slici 1, prosječna visina svih biljaka u testu provenijencija u proljeće 2012. godine, na bazi mjerenja 2516 biljaka starih četiri godine, iznosila je 50,3 $\mathrm{cm}$, minimalna $7,5 \mathrm{~cm}$, maksimalna $206,1 \mathrm{~cm}$, a standardna devijacija $23,7 \mathrm{~cm}$.
U proljeće 2013. godine mjerene su preživjele 2274 biljke stare pet godina, čija je prosječna visina bila $79,8 \mathrm{~cm}$, minimalna $15,8 \mathrm{~cm}$, a maksimalna $263,8 \mathrm{~cm}$ uz standardnu devijaciju $33,7 \mathrm{~cm}$.

U proljeće 2014. godine u testu je ostalo 2245 biljaka, a njihova prosječna visina bila je $117,8 \mathrm{~cm}$. Minimalna visina bila je $23,0 \mathrm{~cm}$, maksimalna $321,0 \mathrm{~cm}$, a standardna devijacija $33,7 \mathrm{~cm}$.

Najmanju prosječnu visinu u proljeće 2012. godine imala je provenijencija Miljevina sa $38,8 \mathrm{~cm}$, a najveću Jelah sa 74,3 $\mathrm{cm}$. U proljeće 2013. godine, najmanju prosječnu visinu imala je provenijencija Stojčevac sa $61,3 \mathrm{~cm}$, dok provenijencija Jelah ostaje provenijencija s najvećom prosječnom visinom koja iznosi 108,4 cm. Miljevina i dalje ima prosječnu visinu vrlo nisku i iznosi $63,0 \mathrm{~cm}$. U proljeće 2014. godine najmanju prosječnu visinu zadržava provenijencija Stojčevac sa 90,8 $\mathrm{cm}$, a najveću provenijencija Jelah sa 152,1 cm (Slika 1).

Najmanji koeficijent varijabilnosti u proljeće 2012. godine ima provenijencija Olovo, a u proljeće 2013. i 2014. godine 


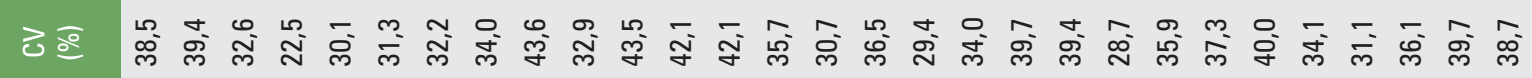

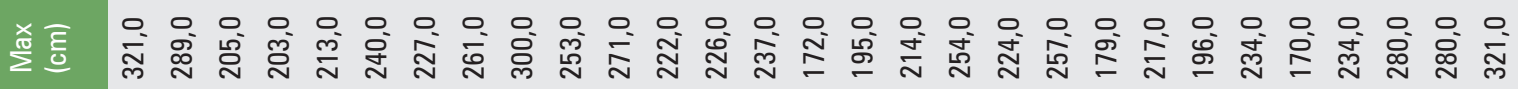

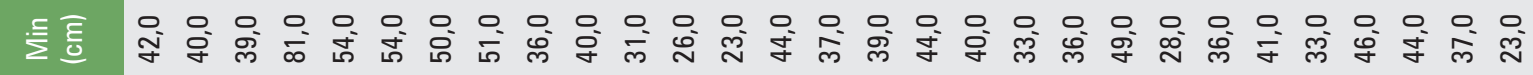

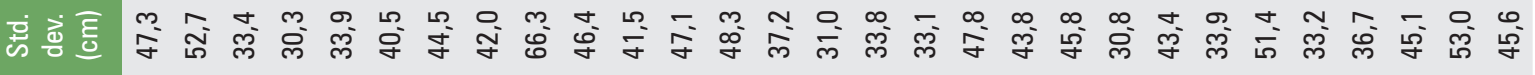

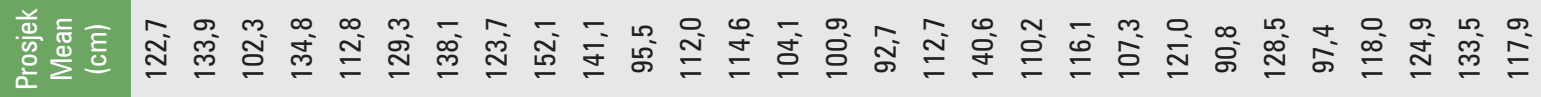

ஸ்유 용 ๙

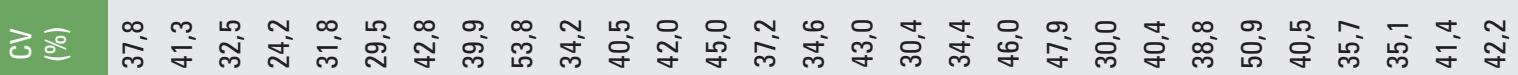

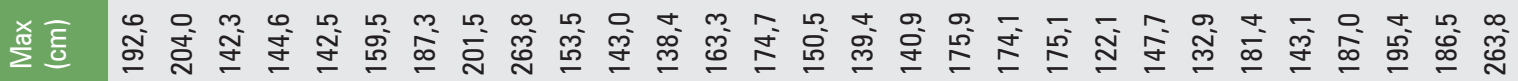

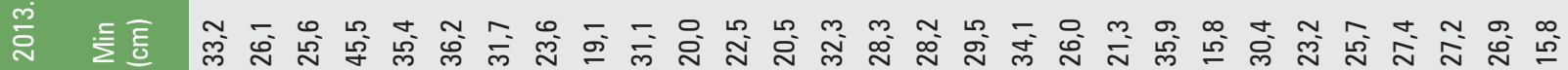

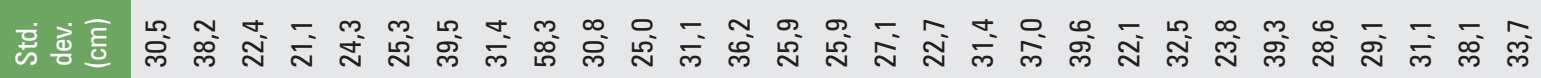

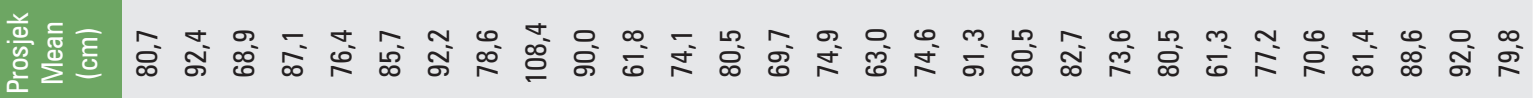

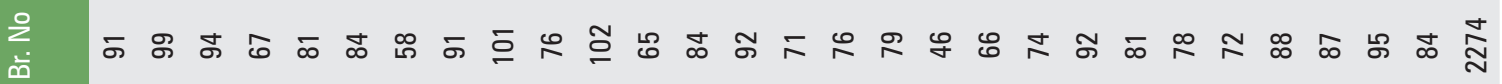

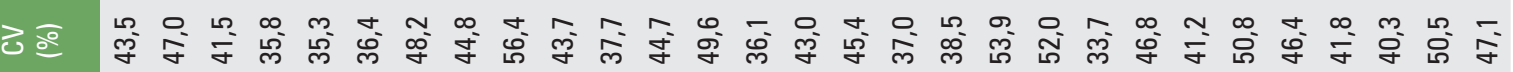

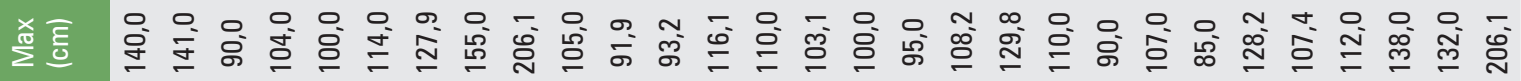

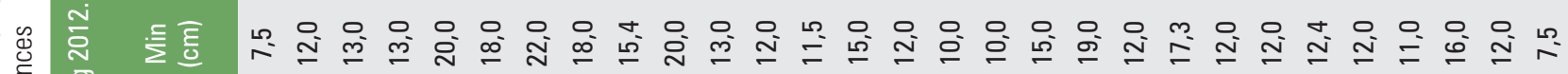

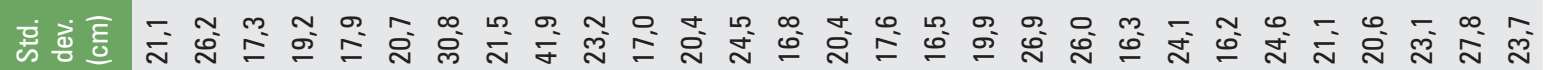

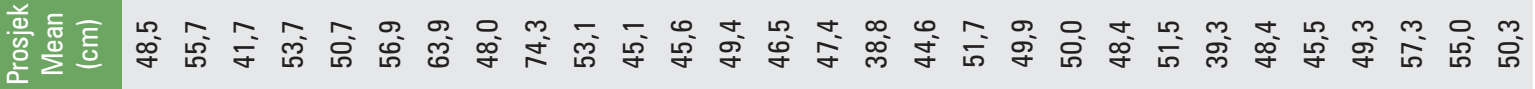


$\mathrm{cm}$

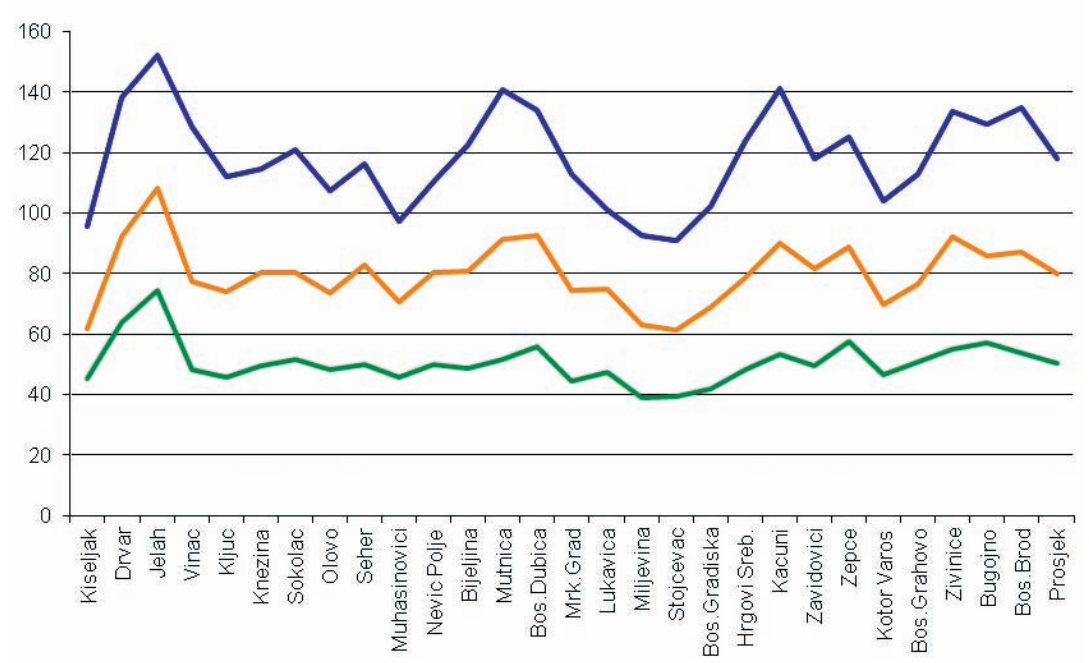

—Proljece/Spring 2012. _ Proljeće/Spring 2013. —Proljeće/Spring 2014.

Slika 1: Srednje vrijednosti svojstva visina po godinama i provenijencijama u cm.

Fig 1: Mean values of height per provenances per years in $\mathrm{cm}$.

provenijencija Bosanski Brod. Najveći koeficijent varijabilnosti za sve tri godine ima provenijencija Jelah.

Najveću standardnu devijaciju za sve tri godine imala je provenijencija s najvećim prosječnim visinama, Jelah, dok je najmanju standardnu devijaciju u proljeće 2012. godine imala provenijencija Stojčevac, a 2013. i 2014. godine provenijencija Bosanski Brod.

Kako je prikazano u tablici 3, analiza varijance za svojstvo visine biljke pokazuje da postoje statistički značajne razlike između provenijencija u svim godinama (F izr $>$ F tab; Sig. $<0,05)$

Duncanov test za visine bilike u 2012. godini pokazuje da se provenijencije grupiraju u deset skupina, uz međusobno preklapanje. Provenijencija Jelah se izdvaja u posebnu skupinu.

U 2013. godini dolazi do grupiranja u jedanaest skupina, gdje se provenijencija Jelah i dalje nalazi u posebnoj skupini.

U 2014. godini broj skupina za svojstvo visina biljaka povećava se na 16 skupina, koje se međusobno preklapaju.

S obzirom da smo u 2012. godini imali deset, u 2013. jedanaest, a u 2014. godini šesnaest skupina, možemo zaključiti da sa starenjem sadnica dolazi do veće diferencijacije.

\subsection{Rezultati promjera vrata korijena - Results for diameter of root collar}

Prosječna vrijednost promjera vrata korijena biljaka starih četiri godine, bazirana na mjerenju 2516 biljaka u proljeće 2012. godine, iznosi $13,1 \mathrm{~mm} \pm 4,7 \mathrm{~mm}$ (Tablica 5, Slika 2).
U proljeće 2013. godine mjerene su 2274 petogodišnje biljke, a prosječna vrijednost promjera vrata korijena iznosila je $20,5 \mathrm{~mm} \pm 6,3 \mathrm{~mm}$. U proljeće 2014. godine, prosječna vrijednost promjera vrata korijena, bazirana na mjerenju 2245 biljaka starih šest godina, je $28,9 \mathrm{~mm} \pm 9,5 \mathrm{~mm}$.

Najmanji srednji promjer vrata korijena u proljeće 2012. godine imala je provenijencija Vinac sa $11,3 \mathrm{~mm}$, a najveći provenijencija Jelah sa $16,2 \mathrm{~mm}$.

Najmanji srednji promjer vrata korijena u proljeće 2013. godine imala je provenijencija Stojčevac sa $17,9 \mathrm{~mm}$, a najveći Jelah sa $23,8 \mathrm{~mm}$. Provenijencija Vinac pomakla se za sedamnaest mjesta, $\mathrm{s}$ prosječnim promjerom vrata korijena $19,9 \mathrm{~mm}$.

Najmanji srednji promjer vrata korijena u proljeće 2014. godine zadržala je provenijencija Stojčevac sa vrijednošću $23,7 \mathrm{~mm}$, a najveći provenijencija Jelah sa $34,7 \mathrm{~mm}$.

Najmanja minimalna vrijednost svojstva promjera vrata korijena u proljeće 2012. godine bila je u provenijenciji Knežina i iznosila 2,4 mm, u proljeće 2013. godine u provenijencijama Kiseljak i Jelah 5,1 mm, a u proljeće 2014. godine u provenijencijama Jelah, Miljevina i Živinice, sa vrijednošću 7,0 mm.

Najveća maksimalna vrijednost svojstva promjera vrata korijena u proljeće 2012. godine bila je $34,0 \mathrm{~mm}$ u provenijencijama Lukavica i Kotor Varoš, u proljeće 2013. godine $51,8 \mathrm{~mm}$ u provenijenciji Jelah, a u proljeće 2014. godine 79,0 mm u provenijencijama Bosanska Dubica i Živinice.

Najmanju standardnu devijaciju pri sva tri mjerenja imala je provenijencija Stojčevac, a najveću Jelah. 
Tablica 3: Analiza varijance visine biljaka po godinama Table 3: Analysis of variance for plant height per years

\begin{tabular}{|c|c|c|c|c|c|c|}
\hline $\begin{array}{c}\text { Izvor variranja } \\
\text { Source of variation }\end{array}$ & $\begin{array}{l}\text { Suma kvadrata } \\
\text { Sum of squares }\end{array}$ & $\begin{array}{c}\text { Broj stupnjeva } \\
\text { slobode } \\
\text { Df }\end{array}$ & $\begin{array}{l}\text { Sredina kvadrata } \\
\text { Mean square }\end{array}$ & $\begin{array}{c}\text { F-vrijednost } \\
\text { (izračunato) } \\
\text { F }\end{array}$ & $\begin{array}{l}\text { F-vrijednost } \\
\text { (tablično) } \\
\text { F-tab }\end{array}$ & $\begin{array}{c}\text { Značajnost } \\
\text { Sig. }\end{array}$ \\
\hline \multicolumn{7}{|c|}{ Proljeće / Spring 2012.} \\
\hline $\begin{array}{l}\text { Između skupina } \\
\text { Between Groups }\end{array}$ & 128438,5 & 27 & 4757,0 & $9,2^{*}$ & 1,49 & 0,0 \\
\hline $\begin{array}{l}\text { Unutar skupina } \\
\text { Within Groups }\end{array}$ & 1285172,9 & 2488 & 516,6 & & & \\
\hline $\begin{array}{l}\text { Ukupno } \\
\text { Total }\end{array}$ & 1413611,4 & 2515 & & & & \\
\hline \multicolumn{7}{|c|}{ Proljeće / Spring 2013.} \\
\hline $\begin{array}{l}\text { Između skupina } \\
\text { Between Groups }\end{array}$ & 268700,6 & 27 & 9951,9 & $9,7^{*}$ & 1,49 & 0,0 \\
\hline $\begin{array}{l}\text { Unutar skupina } \\
\text { Within Groups }\end{array}$ & 2314714,2 & 2246 & 1030,6 & & & \\
\hline $\begin{array}{l}\text { Ukupno } \\
\text { Total }\end{array}$ & 2583414,8 & 2273 & & & & \\
\hline \multicolumn{7}{|c|}{ Proljeće / Spring 2014.} \\
\hline $\begin{array}{l}\text { Između skupina } \\
\text { Between Groups }\end{array}$ & 572766,9 & 27 & 21213,6 & $11,5^{*}$ & 1,49 & 0,0 \\
\hline $\begin{array}{l}\text { Unutar skupina } \\
\text { Within Groups }\end{array}$ & 4083455,1 & 2217 & 1841,9 & & & \\
\hline $\begin{array}{l}\text { Ukupno } \\
\text { Total }\end{array}$ & 4656222,0 & 2244 & & & & \\
\hline
\end{tabular}

Tablica 4: Duncanov test za svojstvo visina po godinama (alpha $=0,05$ )

Table 4: Duncan's test for plant height per years (alpha $=0,05$ )

\begin{tabular}{ccccccccccccccccccc} 
Godina & Br. & \multicolumn{11}{c}{ Skupine provenijencija/ Groups of provenance } \\
Year & No. & 1 & 2 & 3 & 4 & 5 & 6 & 7 & 8 & 9 & 10 & 11 & 12 & 13 & 14 & 15 & 16 \\
\hline 2012. & 2516 & 8 & 15 & 17 & 17 & 17 & 15 & 15 & 13 & 2 & 1 & - & - & - & - & - & - \\
2013. & 2274 & 6 & 6 & 14 & 14 & 14 & 14 & 11 & 11 & 11 & 14 & 1 & - & - & - & - & - \\
2014. & 2245 & 7 & 7 & 7 & 9 & 10 & 10 & 10 & 11 & 10 & 9 & 9 & 9 & 9 & 8 & 8 & 4
\end{tabular}

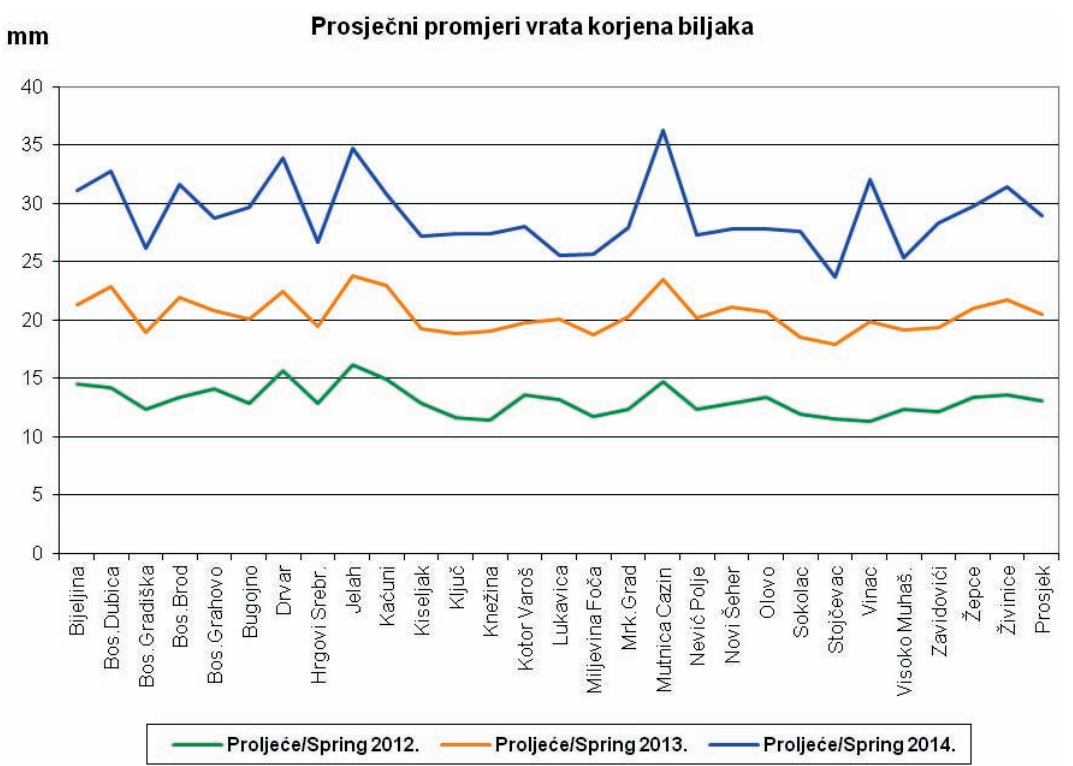

Slika 2: Srednje vrijednosti svojstva promjera vrata korijena po godinama i provenijencijama

Pic 2: Mean values of root collar per provenances per year 


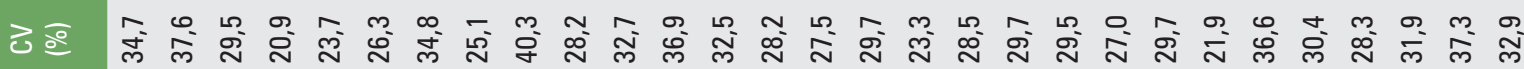

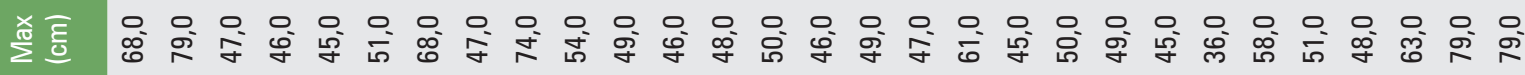

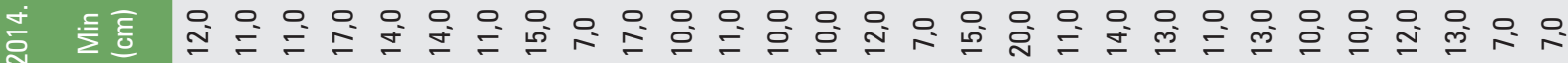

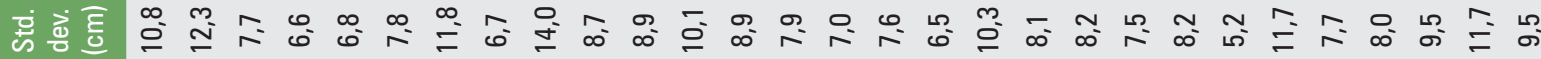

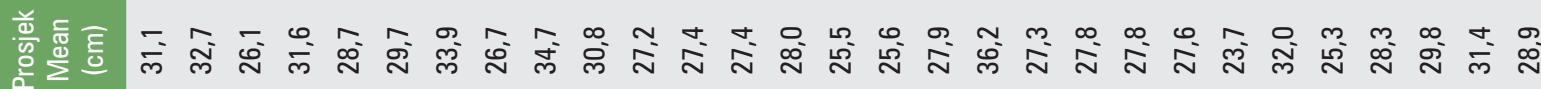

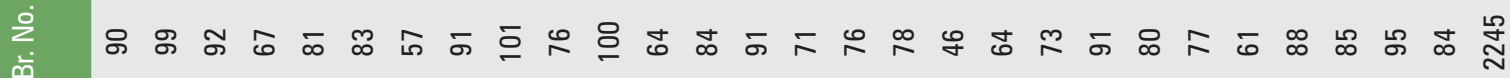

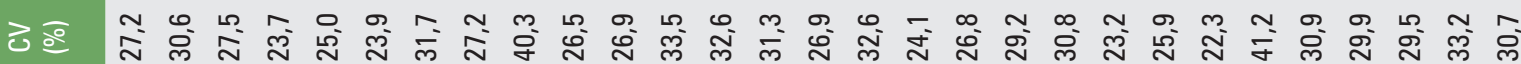

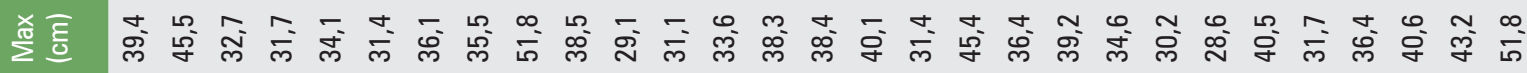

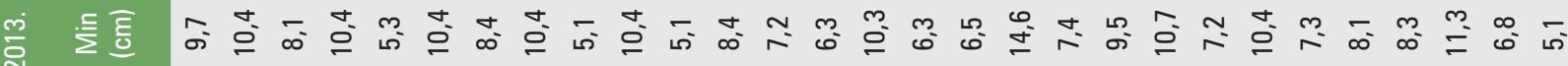

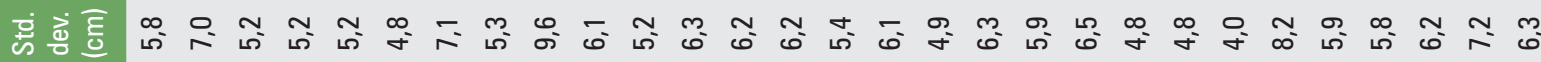

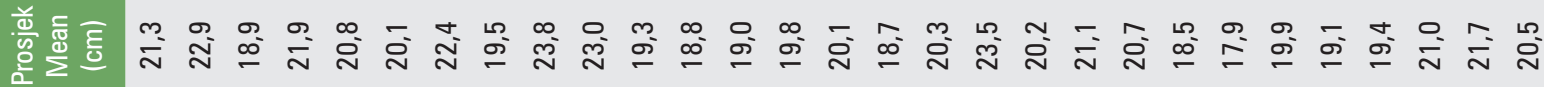

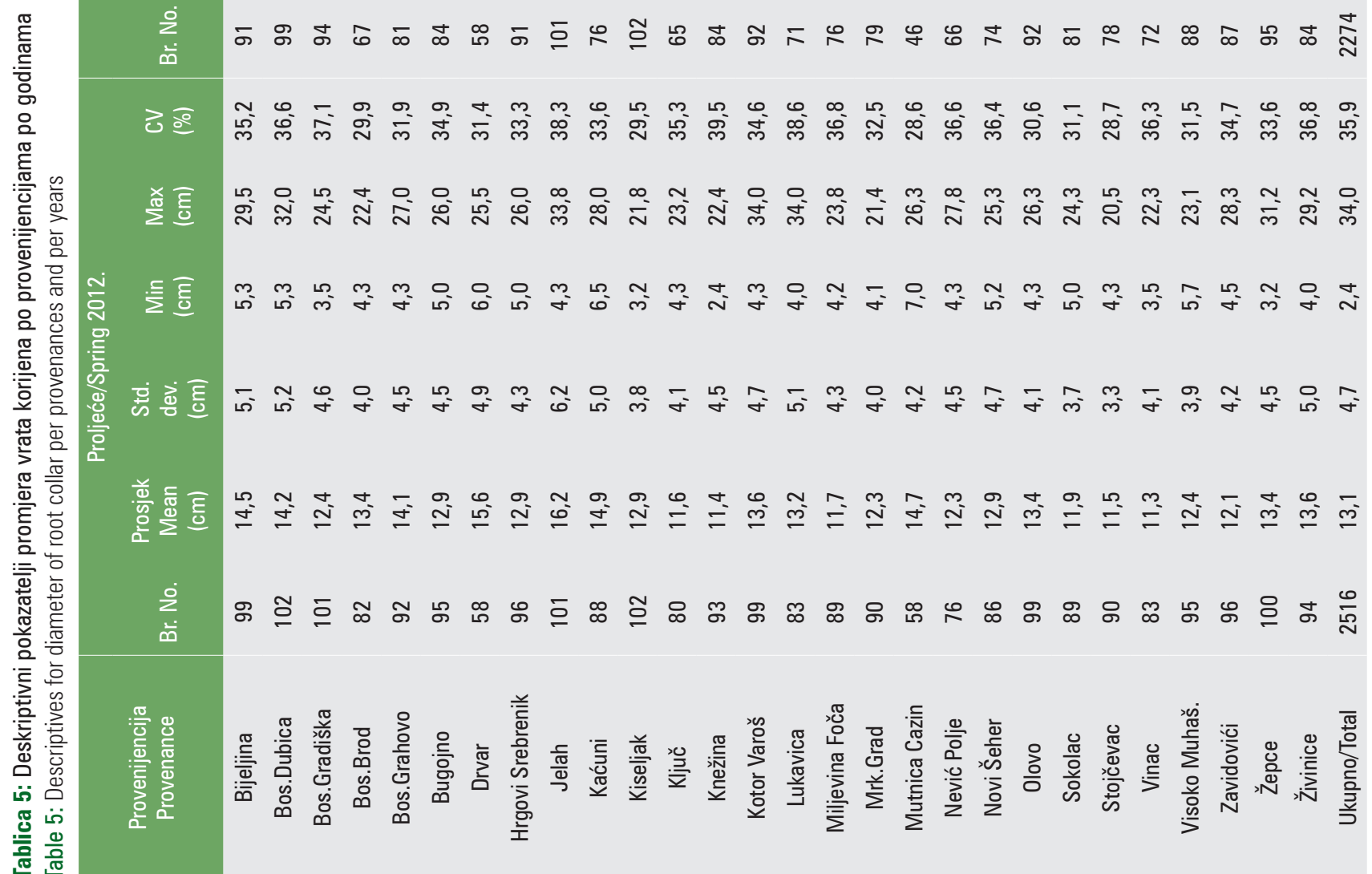


Tablica 6: Analiza varijance promjera vrata korijena po godinama Table 6: Analysis of variance of diameter of root collar per years

\begin{tabular}{|c|c|c|c|c|c|c|}
\hline $\begin{array}{l}\text { Izvor variranja } \\
\text { Source of variation }\end{array}$ & $\begin{array}{l}\text { Suma kvadrata } \\
\text { Sum of squares }\end{array}$ & $\begin{array}{c}\text { Broj stupnjeva } \\
\text { slobode } \\
\text { Df }\end{array}$ & $\begin{array}{l}\text { Sredina kvadrata } \\
\text { Mean square }\end{array}$ & $\begin{array}{c}\text { F-vrijednost } \\
\text { (izračunato) } \\
\text { F }\end{array}$ & $\begin{array}{c}\text { F-vrijednost } \\
\text { (tablično) } \\
\text { F-tab }\end{array}$ & $\begin{array}{l}\text { Značajnost } \\
\text { Sig. }\end{array}$ \\
\hline \multicolumn{7}{|c|}{ Proljeće/Spring 2012.} \\
\hline $\begin{array}{l}\text { Između skupina } \\
\text { Between Groups }\end{array}$ & 3821,884 & 27 & 141,551 & $6,9^{*}$ & 1,49 & 0,0 \\
\hline $\begin{array}{l}\text { Unutar skupina } \\
\text { Within Groups }\end{array}$ & 50750,139 & 2488 & 20,398 & & & \\
\hline $\begin{array}{l}\text { Ukupno } \\
\text { Total }\end{array}$ & 54572,023 & 2515 & & & & \\
\hline \multicolumn{7}{|c|}{ Proljeće/Spring 2013.} \\
\hline $\begin{array}{l}\text { Između skupina } \\
\text { Between Groups }\end{array}$ & 5546,231 & 27 & 205,416 & $5,5^{*}$ & 1,49 & 0,0 \\
\hline $\begin{array}{l}\text { Unutar skupina } \\
\text { Within Groups }\end{array}$ & 83407,228 & 2246 & 37,136 & & & \\
\hline $\begin{array}{l}\text { Ukupno } \\
\text { Total }\end{array}$ & 88953,458 & 2273 & & & & \\
\hline \multicolumn{7}{|c|}{ Proljeće/Spring 2014.} \\
\hline $\begin{array}{l}\text { Između skupina } \\
\text { Between Groups }\end{array}$ & 18485,151 & 27 & 684,635 & $8,3^{*}$ & 1,49 & 0,0 \\
\hline $\begin{array}{l}\text { Unutar skupina } \\
\text { Within Groups }\end{array}$ & 181974,674 & 2217 & 82,081 & & & \\
\hline $\begin{array}{l}\text { Ukupno } \\
\text { Total }\end{array}$ & 200459,824 & 2244 & & & & \\
\hline
\end{tabular}

Tablica 7: Duncanov test promjera vrata korijena po godinama (alpha $=0,05$ ) Table 7. Table 4: Duncan's test for diameter of root collar per years (alpha $=0,05$ )

\begin{tabular}{cccccccccccccc} 
Godina & Br. & \multicolumn{10}{c}{ Skupine provenijencija / Groups of provenance } \\
Year & No. & 1 & 2 & 3 & 4 & 5 & 6 & 7 & 8 & 9 & 10 \\
\hline 2012. & 2516 & 11 & 14 & 12 & 14 & 15 & 13 & 10 & 10 & 5 & 3 \\
2013. & 2274 & 15 & 17 & 17 & 17 & 15 & 14 & 13 & 10 & 9 & 7 \\
2014. & 2245 & 6 & 16 & 13 & 10 & 10 & 8 & 8 & 7 & 5 & 3
\end{tabular}

Najmanji koeficijent varijabilnosti u proljeće 2012. godine imala je provenijencija Mutnica, u proljeće 2013. godine Stojčevac, a u proljeće 2014. Bosanski Brod. Najveći koeficijent varijabilnosti u proljeće 2012. godine imala je provenijencija Knežina, u proljeće 2013. godine Vinac, a u proljeće 2014. godine provenijencija Jelah.

Analiza varijance za promjer vrata korijena (Tablica 6) pokazuje da postoje statistički značajne razlike između provenijencija u svim godinama (F izračunato > F tablično; Sig. $<0,05)$.

Duncanov test za svojstvo promjer vrata korijena za proljeće 2012., 2013. i 2014. godine pokazuje da se provenijencije grupiraju u deset skupina, koje se međusobno u velikoj mjeri preklapaju.

Za razliku od svojstva visine, u ovoj ranoj fazi ne možemo reći da se sa starošću biljaka povećava diferencijacija provenijencija za svojstvo promjera vrata korijena.

\section{RASPRAVA DISCUSSION}

Ovo su prva istraživanja provenijencija hrasta lužnjaka u Bosni i Hercegovini. Za razliku od Bosne i Hercegovine $\mathrm{u}$ Europi su pokusi provenijencija hrasta lužnjaka podizani prije 80-100 godina (Hauch 1909, Cieslar 1923), a u susjednoj Hrvatskoj istraživanja su započeta 1988. godine (Gračan 1995, 1996) i nastavljena kasnije (Popović i dr. 2014). Razloge za slabiji interes u Bosni i Hercegovini za istraživanje provenijencija hrasta lužnjaka nalazimo u njegovoj maloj zastupljenosti, odnosno jako velikoj fragmentiranosti populacija, što je izravna posljedica velike eksploatacije ove vrste u razdoblju od 1839. do 1914. godine (Begović 1960, 1978; Memišević 2008).

Morfološke analize bazirali smo na mjerenju visina biljka i promjera vrata korijena trogodišnjih, četverogodišnjih i petogodišnjih biljaka u pokusu provenijencija podrijetlom iz 
Bosne i Hercegovine. Kod svih analiziranih morfoloških svojstava dobili smo statistički značajne razlike između istraživanih provenijencija, kao i drugi istraživači (Cieslar, 1923; Gračan, 1995; Perić Perić 2001; Perić i dr. 2000, 2003, 2006; Roth, 2003, 2006...).

Uspoređujući rezultate do kojih su došli Popovići dr. (2014), gdje je prosječna visina za biljke starosti četiri godine 162,3 $\mathrm{cm}, \mathrm{s}$ intervalom između 154,8 i $179,3 \mathrm{~cm}$, naše visine četverogodišnjih biljaka (mjerene u proljeće 2012. godine) su dosta manje. Prosječna vrijednost visine iznosila je $50,3 \mathrm{~cm}$ $\mathrm{u}$ intervalu od 38,8 do $74,3 \mathrm{~cm}$.

Prosječna visina biljaka starosti pet godina u istraživanju Popović i dr. (2014) iznosila je $182,7 \mathrm{~cm}$, a maksimalna $204,5 \mathrm{~cm}$. Naša prosječna visina od $79,8 \mathrm{~cm}$ za starost od pet godina (visine mjerene u proljeće 2013. godine) nešto je veća od intervala od 496,7 do 606,7 mm koji je Roth (2006) utvrdio u rasadniku Hrvatskog šumarskog instituta, odnosno 607,8 do 720,5 mm na lokalitetu Sedlarac, za biljke starosti $3+2$.

Srednja vrijednost promjera vrata korijena od 20,5 $\mathrm{mm}$ dobijena u ovom istraživanju u proljeće 2013. godine (biljke stare pet godina) dosta je iznad intervala $8,87-11,28 \mathrm{~mm}$, koliko je utvrdio Roth (2006) u rasadniku Jastrebarsko, odnosno 12,69 - 13,65 mm na lokalitetu Sedlarac. Razloge za razlike između dva istraživanja možemo tražiti u primijenjenim agrotehničkim mjerama tijekom proizvodnje u rasadniku, kao i različitim uvjetima restiranja.

Duncanov test za svojstvo visine biljaka pokazuje podjelu na sve veći broj skupina s povećanjem starosti, pa možemo zaključiti da se sa starošću pokusa provenijencija povećava i diferenciranost između njih po svojstvu visine. To se ne može reći za svojstvo promjera vrata korijena, jer je Duncanov test pokazao grupiranje $\mathrm{u}$ isti broj skupina za tri uzastopne godine.

Treba se također osvrnuti i na samu veličinu žireva koju mi nismo analizirali, a koju analizira Bogdan i dr. (2009). O tome detaljno izvještavaju u svojim istraživanjima Burger (1921), Kahrl-Urban (1959) i Kleinschmit (1993), a veličina žira može se odraziti na biljke starosti do šest godina. Za razliku od njih Cieslar (1923) koji se također bavio tom problematikom zaključuje da razlike između biljaka na temelju veličine žira ostaju vidljive i do 15 . godine. Na temelju tih saznanja, sve usporedbe koje su provedene ne mogu biti konačne, nego tek nakon dužeg razdoblja, što će potvrditi ili odbaciti naša daljnja istraživanja.

U istraživanjima koje su proveli Oppermann (1932) te Naidenova i Kostov (1979; prema Kleinschmit 1993) zaključujemo da su južne provenijencije nešto bržeg rasta od sjevernih. Mi to u našem istraživanju nismo mogli potvrditi zbog specifičnosti ekoloških prilika i genetske strukture lužnjaka iz Bosne i Hercegovine, te relativno malog područja na kojemu je provedeno istraživanje. Tako najvišu prosječnu visinu ima provenijencija Jelah koja je sjeverna, ali na rubu Panonskog bazena, dok su južne provenijencije smještene u kraškim poljima i sa većih nadmorskih visina, te imaju nešto manje visine biljaka.

\section{ZAKLJUČCI CONCLUSIONS}

Na temelju rezultata istraživanja morfoloških svojstava hrasta lužnjaka u pokusu provenijencija u Bosni i Hercegovini možemo zaključiti sljedeće:

1. Sva istraživana svojstva pokazala su analizom varijance da su prisutne statistički značajne razlike između istraživanih provenijencija, a što je potvrđeno i uporabom Duncanovog testa.

2. Srednja vrijednost visine biljaka za sve provenijencije za 2012. godinu (biljke stare četiri godine) iznosila je $50,3 \mathrm{~cm}$ $\pm 23,7 \mathrm{~cm}$, za 2013. godinu (biljke stare pet godina) $79,8 \mathrm{~cm}$ $\pm 33,7 \mathrm{~cm}$, a za 2014. godinu (šestogodišnje biljke) $117,9 \pm$ $45,6 \mathrm{~cm}$.

3. Prosječna vrijednost promjera vrata korijena za 2012. godinu iznosi $13,1 \mathrm{~mm} \pm 4,7 \mathrm{~mm}$, za 2013. godinu $20,5 \mathrm{~mm}$ $\pm 6,3 \mathrm{~mm}$, a za 2014 . godinu $28,9 \pm 9,5 \mathrm{~mm}$.

6. S obzirom na dobivenu varijabilnost između istraživanih provenijencija, dobiveni rezultati trebaju biti korišteni prilikom planiranja mjera očuvanja i reintrodukcije hrasta lužnjaka u Bosni i Hercegovini.

7. Potrebno je nastaviti s daljnjim istraživanjima, jer su rezultati koji se dobiju u ranom juvenilnom stadiju nepotpuni i opterećeni brojnim nedostacima.

Zahvala: Ovo istraživanje je realizirano uz svesrdnu pomoć djelatnika Rasadnika Lugovi - Žepče, kao i djelatnika Šumarije Žepče, a koji posluju u okviru JP Šumsko Privredno Društvo ZE-DO Kantona d.o.o. Zavidovići te im dugujemo veliku zahvalnost. Ovdje posebno ističemo Ivicu Murlina dipl. inž. šum. koji se uvijek nađe pri ruci tijekom rada i izmjera u pokusu, kao i njegovoj zaštiti.

\section{LITERATURA REFERENCES}

- Ballian D., P. Belletti, D. Ferrazzini, F. Bogunić, D. Kajba 2010: Genetic variability of pedunculate oak (Quercus robur L.) in Bosnia and Herzegovina. Periodicum biologorum, 112 (3): 353362.

- Ballian D., F. Mekić, I. Murlin, M. Memišević, F. Bogunić 2011: Preliminarni rezultati istraživanja provenijencija hrasta lužnjaka (Quercus robur L.) u Bosni i Hercegovini u pokusu Žepče. Naše šume, 24-25:3-16.

- Bašić, N., J. Kapić, D. Ballian 2007: Morfometrijska analiza lista hrasta lužnjaka, Rad. Šumar. inst. Jastrebarsko 42 (1): 5-18. 
- Begić A., D. Ballian 2009: Hrast lužnjak (Quercus robur L.) u Posuškom polju. Naše šume 14/15: 42-44.

- Begović B. 1960: Strani kapital u šumskoj privredi Bosne i Hercegovine za vrijeme otomanske vladavine. Radovi Šumarskog fakulteta i Instituta za šumarstvo i drvnu industriju u Sarajevu, Godina V, Broj 5: 1- 243.

- Begović B. 1978: Razvojni put šumske privrede u Bosni i Hercegovini u periodu austrougarske uprave (1878-1918) sa posebnim osvrtom na eksploataciju šuma i industrijsku preradu drveta. Akademija nauka i umjetnosti Bosne i Hercegovine, Djela, Knjiga LIV, Odjeljenje društvenih nauka, Knjiga 31: 1-204.

- Bobinac M. 2011: Ekologija i obnova higrofilnih lužnjakovih šuma Ravnog Srema. Šumarski institut Jastrebarsko, Zagreb. str, 1-294.

- Bogdan S., A. Jelušić, M. Ivanković 2009: Testiranje genetske varijavilnosti hrasta lužnjaka (Quercus robur L.) iz sjemenskih sastojina u Hrvatskoj - prvi rezultati. In: (ed.) Matić S., Zbornik radova sa znanstvenog skupa: Šume hrasta lužnjaka u promjenjenim stanišnim i gospodarskim uvjetima HAZU- Centar za znanstveni rad Vinkovci. str. 169 - 181.

- Burger H. 1921: Über morphologische und biologische Eigenschaften der Stiel- und Traubeneiche und ihre Erziehungsweise im Forstgarten. Mitt Schweiz Anst Forstl Versuchswas 11

- Cieslar A. 1923: Untersuchungen über die wirtschaftliche Bedeutung der Herkunft des Saatgutes der Stieleiche. Centralbl Ges Forstwes.

- Franjić J. 1993: Veličina žira kao pokazatelj individualne varijabilnosti hrasta lužnjaka (Quercus robur L.). Glas. Šum. pokuse, Posebno izd. 4: 195-206.

- Franjić J. 1993a: Morfometrijska analiza lista i ploda hrasta lužnjaka (Quercus robur L.) u Hrvatskoj. Magistarski rad. Zagreb. Str. 1-150.

- Franjić J. 1994: Morphometric leaf analysis as an indicator of common oak (Quercus robur L.) variability in Croatia. Ann. Forest. 19(1): 1-32

- Franjić J. 1996: Multivarijantna analiza svojstava lista posavskih i podravskih populacija hrasta lužnjaka (Quercus robur L., Fagaceae) u Hrvatskoj. Hrvatska akademija znanosti i umjetnosti, Zagreb. Anali za šumarstvo 21 (2): 1-60.

- Gračan J. 1995: Rezultati uspijevanja provenijencija hrasta lužnjaka na lokalitetu Gajno. Rad. Šumar. inst. Jastrebarsko, 31 (1/2): 149 - 160 .

- Gračan J. 1996: Oplemenjivanje hrasta lužnjaka. - Masovna selekcija. In. Hrast lužnjak (Quercus robur L.)u Hrvatskoj, (ed) Klepac. D. Vinkovci - Zagreb.

- Hauch L.A. 1909: Erblichkeit bei Buche und Eiche. Centralbl. Gesamte Forstwes. 35: 333-348.

- Jovančević M. 1966: Brdski lužnjak - posebna rasa, Šumarstvo 3 (5): 3-15.

- Jovančević M. 1968: Brdski lužnjak - posebna rasa II. Rano testiranje genetsko-fizioloških osobina, Šumarstvo 7(8): 3-16.

- Kleinschmit J. 1993: Interspecific variation of growth and adaptivetraits in European oak species. Ann Sci For 50(1): 166-185

- Klepac D. 1988: Uređivanje šuma hrasta lužnjaka, Glasnik za šumske pokuse 24: 117-132.

- Kramer E.M. 2001: A Mathematical Model of Auxin-mediated Radial Growth in Trees. J. Theor. Biol. 208 (4): 387-397.
- Matić S. 2009: Gospodarenje šumama hrasta lužnjaka (Quercus robur L.) u promjenjenim stanišnim i strukturnim uvjetima. In: (ed.) Matić S., Zbornik radova sa znanstvenog skupa: Šume hrasta lužnjaka u promjenjenim stanišnim i gospodarskim uvjetima HAZU- Centar za znanstveni rad Vinkovci. Str. 1 - 22.

- Memišević M. 2008: Eksploatacija kao razlog nestanka hrasta lužnjaka (Quercus robur, L.) u periodu od 1878. do 1914. godine u Bosni i Hercegovini. Naše šume. 12-13:39-40

- Memišević M. 2010: Unutarpopulacijska i međupopulacijska varijabilnost nekih morfoloških karakteristika hrasta lužnjaka (Quercus robur L.) u području Zapadnog Balkana. Magistarski rad, Šumarski fakultet Univerziteta u Sarajevu. Str. 1-148.

- Naidenova T.S., K.D. Kostov 1979: Rate of photosynthesis and transpiration of Quercus robur in relation to seed origin. Gorskostop Nauka 16, 3-10 (prema: Kleinschmit, J. 1993: Intraspecific variation of growth and adaptive traits in European oak species; Ann Sci For 50(1): 166-185).

- Opperman A. 1932: Egens Traeformer og racer. Forstl Forsøgsvaes Dan. 12: 1-400.

- Perić S. 2001: Prvi rezultati o produkciji drvne mase u pokusu provenijencija hrasta lužnjaka (Quercus robur L.) u Hrvatskoj. Znanost u potrajnom gospodarenju hrvatskim šumama. Znanstvena knjiga. Str. 223-232.

- Perić S., Gračan J., Dalbelo-Bašić B. 2000: Flushing variability of pedunculate oak (Quercus robur L.) in the provenance experiment in Croatia. Glas. šum. pokuse 37: 395-412.

- Perić S., Jazbec A., Gračan J. 2003: Grouping of pedunculate oak provenances on the basis of biomass by applying cluster analysis. $25^{\text {th }}$ International Conference Information Technology Interfaces ITI 2003, June 16-19 2003, Cavtat, Croatia. Str. 217-221.

- Perić S., Jazbec A., Medak J., Topić V., Ivanković M. 2006: Analysis of biomass of 16th Pedunculate Oak provenances. Periodicum biologorum, 108(6):649-653.

- Perić S., Jazbec A., Medak J., Ivanković M., Margaletić J. 2007: Forest tree-breeding traits of pedunculate oak provenances in Croatia. IUFRO kongres »Tree biotechnology 2007», Azores, Abstracts. Str. 23.

- Perić S., Tijardović M., Jazbec A., Ivanković M., Medak J. 2008: Uspijevanje provenijencija hrasta lužnjaka (Quercus robur L.) u 20-godišnjim pokusima u spačvanskom i pokupskom bazenu. Šume hrasta lužnjaka u promijenjenim stanišnim i gospodarskim uvjetima, Zagreb, Sažeci/Summaries. Str. 40-43.

- Pintarić K. 2002: Šumskouzgojna svojstva i život važnijih vrsta šumskog drveća. Udruženje šumarskih inžinjera i tehničara Federacije BiH (UŠIT). Sarajevo. Str. 1-221.

- Popović M., M. Ivanković, S. Bogdan 2014: Varijabilnost visinskog rasta i preživljenja potomstava iz sjemenskih sastojina hrasta lužnjaka (Quercus robur, L.) u pokusnom nasadu „Jastrebarski Lugovi“ - prvi rezultati. Šumarski list, 1-2: 155-165.

- Roth V. 2003: Neki pokazatelji rasta hrasta lužnjaka (Quercus robur L.) iz sjemenskih zona i rajona Hrvatske u rasadničkom testu. Rad. Šumar. inst. Jastrebarsko, 38 (2): 195-210.

- Roth V. 2006: Rast biljaka hrasta lužnjaka (Quercus robur L.) iz različitih sjemenskih zona i rajona Hrvatske, tijekom prvih dviju godina poljskog testa

- Slade D., Z. Škvorc, D. Ballian, J. Gračan, D. Papeš 2008: The chloroplast DNA polymorphisms of White Oaks of section Quercus in the Central Balkans. Silvae Genetica 57 (4-5): $227-$ 234. 


\section{Summary}

Natural populations of pedunculate oak (Quercus robur L.) in Bosnia and Herzegovina are small and scattered. They differ from those located in their optimum in Central Europe and due to their specific genetic structure they play a significant role in preservation of pedunculate oak diversities in Europe.

The aim of this research is to determine the variability of the remaining pedunculate oak populations in Bosnia and Herzegovina.

Measuring of height of plants and diameter of root collar was conducted in provenance test in Žepče in the spring of 2012, 2013 and 2014. Plants from all 28 provenances have been measured.

In 2012, Miljevina provenance contained the minimum average height $-38,8 \mathrm{~cm}$, and the maximum height was found in Jelah $-74,3 \mathrm{~cm}$. In 2013, Stojčevac provenance contained the minimum average height $-61,3$ $\mathrm{cm}$, while Jelah remained provenance with the maximum average height $-108,4 \mathrm{~cm}$. Average height of Miljevina provenance still remained low $-63,0 \mathrm{~cm}$. In 2014, Stojčevac provenance kept the minimum average height $-90,8 \mathrm{~cm}$ - while Jelah kept the maximum height - 151,2 cm.

In 2012, Vinac provenance had the smallest average diameter of root collar $-11,3 \mathrm{~mm}$, while Jelah provenance had the biggest average diameter of root collar - 16,2 mm. In 2013, Stojčevasprovenance contained the smallest average diameter of root collar $-17,9 \mathrm{~mm}$ and the biggest average diameter was found in Jelah provenance $-23,8 \mathrm{~mm}$. Vinac provenance moved from 17th position with its average root collar diameter of $19.9 \mathrm{~mm}$. The smallest average root collar diameter in 2014 remained in Stojčevac provenance $-23,7 \mathrm{~mm}$, while the biggest average diameter remained in Jelah provenance $-34,7 \mathrm{~mm}$. Analysis of variance has pointed at the statistically significant differences between populations with regard to all analyses characteristics. All traits tested using variance analysis and Duncan's test showed statistically significant differences between populations.

Due to the resulting variability between studies provenances, the results should be used when planning conservation measures and reintroduction of pedunculate oak in Bosnia and Herzegovina.

Research needs to be continued, because the results obtained in the early juvenile stage are incomplete and burdened with numerous disadvantages.

KEY WORDS: pedunculate oak, provenance test, morphological variability 